University of Nebraska - Lincoln

DigitalCommons@University of Nebraska - Lincoln

Faculty Papers and Publications in Animal

Science

Animal Science Department

2013

\title{
Effect of corn bran and steep inclusion in finishing diets on diet digestibility, cattle performance, and nutrient mass balance
}

\author{
K. M. Sayer \\ University of Nebraska-Lincoln \\ Crystal D. Buckner \\ University of Nebraska-Lincoln, cbuckner2@unl.edu \\ Galen E. Erickson \\ University of Nebraska-Lincoln, gerickson4@unl.edu \\ Terry Klopfenstein \\ Universitiy of Nebraska-Lincoln, tklopfenstein1@unl.edu \\ C.N. Macken \\ University of Nebraska-Lincoln \\ See next page for additional authors
}

Follow this and additional works at: https://digitalcommons.unl.edu/animalscifacpub

Sayer, K. M.; Buckner, Crystal D.; Erickson, Galen E.; Klopfenstein, Terry; Macken, C.N.; and Loy, T.W., "Effect of corn bran and steep inclusion in finishing diets on diet digestibility, cattle performance, and nutrient mass balance" (2013). Faculty Papers and Publications in Animal Science. 789.

https://digitalcommons.unl.edu/animalscifacpub/789

This Article is brought to you for free and open access by the Animal Science Department at DigitalCommons@University of Nebraska - Lincoln. It has been accepted for inclusion in Faculty Papers and Publications in Animal Science by an authorized administrator of DigitalCommons@University of Nebraska - Lincoln. 


\section{Authors}

K. M. Sayer, Crystal D. Buckner, Galen E. Erickson, Terry Klopfenstein, C.N. Macken, and T.W. Loy 


\title{
Effect of corn bran and steep inclusion in finishing diets on diet digestibility, cattle performance, and nutrient mass balance ${ }^{1}$
}

\author{
K. M. Sayer, C. D. Buckner, G. E. Erickson, ${ }^{2}$ T. J. Klopfenstein, C. N. Macken, and T. W. Loy \\ Department of Animal Science, University of Nebraska, Lincoln 68583-0908
}

\begin{abstract}
One metabolism trial and 2 finishing trials were conducted to evaluate the effects of adding corn bran and steep liquor (steep) in replacement of dry-rolled corn (DRC) on diet digestibility, cattle performance, and nutrient mass balance in open feedlot pens. The metabolism trial (Exp. 1) used 8 ruminally cannulated heifers in a $4 \times 4$ Latin square design and the 2 finishing trials used 128 steer calves fed for 167 d (Exp. 2) and 256 yearling steers fed for $126 \mathrm{~d}$ (Exp. 3). Dietary treatments for all trials included a DRC-based control (CON), 30\% corn bran (30/0), 30\% corn bran plus $15 \%$ steep (30/15), and $45 \%$ corn bran plus $15 \%$ steep (45/15), in which byproducts replaced DRC and molasses in the diet (DM basis). Diets were not isonitrogenous or isoenergetic. In the metabolism trial, feeding the by-product diets produced greater rumen $\mathrm{pH}(5.95)$ than $\mathrm{CON}$ (5.76; $P<$ $0.01)$. Total tract $\mathrm{DM}$ and $\mathrm{OM}$ digestibility were greater for heifers fed CON than the by-product diets $(P<0.01)$.
\end{abstract}

Dry matter and NDF ruminal disappearance $(\% / \mathrm{h})$ of corn bran were numerically less for cattle fed the CON diet than the by-product diets ( 2.36 vs. 2.84 and 0.72 vs. 1.66 , respectively). In the performance trials, steers fed the by-product diets consumed more $\operatorname{DM}(P=0.06)$ and G:F was either similar for all diets in Exp. $2(P=0.56)$ or less for cattle fed 30/0 than the other diets in Exp. $3(P=$ $0.05)$. Percent $\mathrm{N}$ loss was reduced in Exp. 2 by including corn bran in diets compared with $\mathrm{CON}(P<0.01)$. However, in Exp. 3, no differences in percent $\mathrm{N}$ loss were detected among treatments $(P=0.16)$, but more $\mathrm{N}$ was removed in the manure from pens where steers were fed by-products $(P=0.01)$. Although steep did not improve diet digestibility, it was beneficial in maintaining cattle performance in the feedlot studies. Feeding corn bran in combination with steep increased manure $\mathrm{N}$ removed and $\mathrm{N}$ in compost, but decreased percent $\mathrm{N}$ lost during the winter months only.

Key words: by-products, cattle, digestibility, nitrogen, nutrient management

(C) 2013 American Society of Animal Science. All rights reserved.

J. Anim. Sci. 2013.91:3847-3858 doi:10.2527/jas2011-3926

\section{INTRODUCTION}

With additional environmental regulations, developing management tools that are economical will allow producers to comply with air and water quality regulations. Feeding corn bran, a source of highly digestible fiber, is an effective means of reducing $\mathrm{N}$ losses in open feedlots (Erickson et al., 2002; Adams et al., 2004). Fecal $\mathrm{N}$ can be more stable than urinary $\mathrm{N}$, as urinary $\mathrm{N}$ can be entirely converted to $\mathrm{NH}_{4}$ within hours (Mobley et al., 1995). Digestible fiber increases the amount of fermentable carbohydrates to the hind gut, which increases fecal $\mathrm{N}$ output (Bierman et al., 1999). However,

\footnotetext{
${ }^{1}$ A contribution of the University of Nebraska Agricultural Research Division, supported in part by funds provided through the Hatch Act.

${ }^{2}$ Corresponding author: gerickson4@unl.edu

Received January 31, 2011.

Accepted April 21, 2013.
}

adding fermentable fiber to the diet reduces diet digestibility and decreases cattle performance (Erickson et al., 2002; Adams et al., 2004).

Corn steep (steep) and corn bran are by-products of the wet corn milling industry that can be fed to cattle (Stock et al., 2000). Steep is a combination of distillers solubles, which is made from alcohol production using yeast fermentation of dextrose, and steep liquor, which is a product of the steeping process (Blanchard, 1992). Corn bran is a fibrous fraction derived from the pericarp of corn during wet milling. Corn bran or steep can be fed to cattle at $15 \%$ or $30 \%$ diet DM, either alone or in combination, and results in increased DMI and ADG, compared with a predominately dry-rolled corn (DRC) $\operatorname{diet}$ (Scott et al., 1997).

Therefore, the objectives of the current study were to evaluate the effect of adding steep to corn bran in DRC-based diets to determine whether performance 
could be improved and still maintain the positive benefits of feeding corn bran on manure $\mathrm{N}$ and $\mathrm{N}$ losses. Specifically, the objectives were to determine the impact of adding $15 \%$ steep to $30 \%$ or $45 \%$ bran diets on: 1 ) diet digestibility, ruminal $\mathrm{pH}$, and VFA production, 2) cattle performance, and 3) $\mathrm{N}$ mass balance, as compared with just $30 \%$ bran or corn alone.

\section{MATERIALS AND METHODS}

All animal use and care procedures followed those reviewed and approved by the University of Nebraska Institutional Animal Care and Use Committee.

\section{Metabolism Study}

Eight ruminally cannulated heifers were used in a replicated $4 \times 4$ Latin square designed metabolism experiment to determine the effects of replacing DRC and molasses with corn bran and steep on diet digestibility and rumen metabolism (Exp. 1). The experiment was conducted from 21 December 2002 to 14 March 2003. Dietary treatments included $0 \%$ corn bran (CON), $30 \%$ corn bran (30/0), $30 \%$ corn bran plus $15 \%$ steep (30/15), and $45 \%$ corn bran plus $15 \%$ steep $(\mathbf{4 5} / \mathbf{1 5}$, DM basis; Table 1). All diets included $15 \%$ corn silage and $5 \%$ dry supplement. The CON and 30/0 diets included $5 \%$ molasses and corn bran replaced DRC. The 30/15 and 45/15 diets replaced all the molasses and part of the DRC. Steep (Cargill Inc., Blair, NE) was a blend of corn steep liquor and distillers solubles, but the proportions can vary, depending on production of the ethanol plant.

Heifers were housed in individual pens $(3 \times 3 \mathrm{~m})$ with slotted floors, in a $25^{\circ} \mathrm{C}$ temperature-controlled room. Four collection periods were used with a 16-d adaptation and 5-d collection. Heifers were fed ad libitum at $0730 \mathrm{~h}$ in feedbunks suspended from load cells (Omega, Stamford, CT). Intake was continuously measured, similar to the system described by Cooper et al. (1999). Daily feed refusals were weighed and sampled $(10 \%$ of daily wet weight) throughout the 5-d collection period. Before the beginning of each 5-d collection period, experimental diets were mixed for the respective collection period and feed ingredients were sampled. During the collection phase, chromic oxide was used as an indigestible marker to calculate total-tract digestibility (Merchen, 1988). One gelatin bolus containing $7.5 \mathrm{~g}$ of $\mathrm{Cr}_{2} \mathrm{O}_{3}$ was administered through the ruminal cannula twice daily at 0730 and $1830 \mathrm{~h}$ on $\mathrm{d} 14$ through 21 to each heifer each period. Fecal grab samples were obtained from the rectum on $\mathrm{d}$ 16 to 21 at 0700,1200 , and $1800 \mathrm{~h}$, then composited daily on an equal wet weight basis.

Rumen fluid was collected before feeding (0730 h) and at 1000, 1200, 1400, 1600, and $1800 \mathrm{~h}$ on d 17 through 21. Ruminal $\mathrm{pH}$ was measured and samples were frozen $\left(-20^{\circ} \mathrm{C}\right)$ until VFA were analyzed. To conduct VFA, rumen fluid samples were thawed and centrifuged at $5,000 \times g$ for $10 \mathrm{~min}$ at $2^{\circ} \mathrm{C}$. Supernatant $(2 \mathrm{~mL})$ was deproteinized after sample collection with $0.5 \mathrm{~mL}$ of 25\% metaphosphoric acid (Erwin et al., 1961) containing 2-ethylbutyrate $(0.2904 \mathrm{~g}$ in $100 \mathrm{~mL})$ and 2-ethylbutyrate was used as an internal standard. Individual VFA were separated and analyzed, using gas chromatography (Erwin et al., 1961; Hewlett-Packard, Avondale, PA).

Feed ingredients, orts, and fecal samples were analyzed for $\mathrm{DM}$ at $60^{\circ} \mathrm{C}$ for $48 \mathrm{~h}$ and ground through a 1-mm Wiley mill (Arthur H. Thomas Co., Philadelphia, PA). Fecal samples were composited by period on an equal dry weight basis. All samples were measured for ash (AOAC, 1996), CP using combustion (AOAC, 1999; method 990.03), and NDF using heat-stable, $\alpha$-amylase and methods described by Van Soest et al. (1991). Fecal samples were analyzed for $\mathrm{Cr}$ concentration using an atomic absorption spectrophotometer (SpectrAA-30, Varian, Inc., Palo Alto, CA), with an air-acetylene flame, according to Williams et al. (1962). Chromium concentration in the feces was used to determine total tract DM, $\mathrm{OM}$, and NDF digestibility of the diets using methods described by Merchen (1988).

An in situ trial was conducted during the final collection period to determine disappearance rates of DRC and corn bran, within each of the 4 dietary treatments. Dacron bags $(5 \times 10 \mathrm{~cm}$; Ankom Technology, Fairport, NY), with a pore size of $50 \mu \mathrm{m}$, were filled with $1.25 \mathrm{~g}$ of dry corn bran (as-is, not ground) or DRC (masticate grind, 6 $\mathrm{mm})$. Two nonincubated bags $(0 \mathrm{~h})$ were also prepared for each sample. Two bags per sample and heifer were placed in mesh bags, presoaked in $39^{\circ} \mathrm{C}$ tap water for 20 min, and incubated in the ventral rumen of each of the 8 heifers at 12, 24, 48, and $96 \mathrm{~h}$. Bags were incubated at different starting time points so they could be removed at the same time. Bags removed from the rumen and nonincubated bags were machine washed $\left(39^{\circ} \mathrm{C}\right)$, using 5 rinse cycles. Each cycle consisted of 1 min of agitation and 2 min of spin. Bags were dried at $60^{\circ} \mathrm{C}$ for $48 \mathrm{~h}$ and then air equilibrated for $24 \mathrm{~h}$ and weighed to determine DM disappearance. In situ bags with corn bran were washed in neutral detergent solution using the ANKOM ${ }^{200} \mathrm{Fi}$ ber Analyzer (Ankom Technology) for determining NDF content. Extent of disappearance was measured for corn bran and DRC at 96 and $48 \mathrm{~h}$, respectively.

Extent of disappearance for corn bran was determined from a first-order derivative, calculated from the best-fit quadratic equation (Microsoft Excel; Microsoft Corporation, Redmond, VA) for the by-product treatments. The extent of corn bran and DRC digestion obtained at 72 and $48 \mathrm{~h}$, respectively, were used and subtracted from the original value $(0 \mathrm{~h})$ to calculate potential 
Table 1. Composition and nutrient analysis for dry-rolled corn (DRC) finishing diets containing 30\% or $45 \%$ corn bran in combination with $15 \%$ steep $^{1}$

\begin{tabular}{|c|c|c|c|c|c|c|c|c|}
\hline \multirow[b]{2}{*}{ Item } & \multicolumn{4}{|c|}{ Metabolism (Exp. 1) and Exp. 2} & \multicolumn{4}{|c|}{ Exp. 3} \\
\hline & $\mathrm{CON}^{2}$ & $30 / 0^{3}$ & $30 / 15^{4}$ & $45 / 15^{5}$ & $\mathrm{CON}$ & $30 / 0$ & $30 / 15$ & $45 / 15$ \\
\hline \multicolumn{9}{|l|}{ Ingredients } \\
\hline $\mathrm{DRC}$ & 75 & 45 & 35 & 20 & 75 & 45 & 35 & 20 \\
\hline Corn bran & - & 30 & 30 & 45 & - & 30 & 30 & 45 \\
\hline Steep & - & - & 15 & 15 & - & - & 15 & 15 \\
\hline Corn silage & 15 & 15 & 15 & 15 & 15 & 15 & 15 & 15 \\
\hline Molasses & 5 & 5 & - & - & 5 & 5 & - & - \\
\hline Dry Supplement & 5 & 5 & 5 & 5 & 5 & 5 & 5 & 5 \\
\hline Finely ground corn & 1.076 & 0.273 & 2.699 & 2.799 & 1.035 & 0.203 & 2.722 & 2.806 \\
\hline Limestone & 1.56 & 1.65 & 1.66 & 1.66 & 1.56 & 1.54 & 1.66 & 1.66 \\
\hline Urea & 1.50 & 0.99 & 0.10 & - & 1.45 & 0.91 & 0.08 & - \\
\hline Sodium chloride & 0.30 & 0.30 & 0.30 & 0.30 & 0.30 & 0.30 & 0.30 & 0.30 \\
\hline Blood meal & 0.15 & 0.75 & - & - & - & - & - & - \\
\hline Feather meal & 0.15 & 0.75 & - & - & 0.42 & 1.81 & - & - \\
\hline Tallow & 0.15 & 0.15 & 0.15 & 0.15 & 0.15 & 0.15 & 0.15 & 0.15 \\
\hline Trace mineral premix 6 & 0.05 & 0.05 & 0.05 & 0.05 & 0.05 & 0.05 & 0.05 & 0.05 \\
\hline Potassium chloride & 0.02 & 0.05 & - & - & - & - & - & - \\
\hline Rumensin- 80 premix ${ }^{7}$ & 0.018 & 0.018 & 0.018 & 0.018 & 0.015 & 0.015 & 0.015 & 0.015 \\
\hline Vitamin A-D-E premix 8 & 0.01 & 0.01 & 0.01 & 0.01 & 0.01 & 0.01 & 0.01 & 0.01 \\
\hline Tylan-40 premix $^{9}$ & 0.013 & 0.013 & 0.013 & 0.013 & 0.009 & 0.009 & 0.009 & 0.009 \\
\hline \multicolumn{9}{|l|}{ Nutrient Composition } \\
\hline $\mathrm{NEg}, \mathrm{Mcal} / \mathrm{kg}$ & 1.43 & 1.33 & 1.45 & 1.41 & 1.43 & 1.34 & 1.45 & 1.41 \\
\hline $\mathrm{OM}^{10}$ & 94.8 & 94.8 & 93.7 & 93.9 & 94.3 & 94.4 & 93.2 & 93.3 \\
\hline $\mathrm{NDF}^{10}$ & 13.4 & 32.5 & 31.6 & 41.2 & - & - & - & - \\
\hline $\mathrm{CP}^{10}$ & 13.5 & 14.0 & 14.2 & 14.2 & 14.3 & 14.9 & 14.9 & 15.1 \\
\hline $\mathrm{DIP}^{11}$ & 8.9 & 9.5 & 9.3 & 10.0 & 9.0 & 10.0 & 9.8 & 10.7 \\
\hline $\mathrm{Ca}^{12}$ & 0.70 & 0.70 & 0.70 & 0.70 & 0.70 & 0.70 & 0.70 & 0.70 \\
\hline $\mathrm{P}^{12}$ & 0.32 & 0.26 & 0.47 & 0.44 & 0.32 & 0.26 & 0.47 & 0.44 \\
\hline
\end{tabular}

${ }^{1}$ Values expressed on a \% DM basis.

${ }^{2} \mathrm{CON}=$ control diet. A different supplement was fed at 6\% diet DM in replacement of DRC for the first phase of finishing Exp. 1 that contained $1.4 \%$ urea, $1.05 \%$ blood meal, and $1.05 \%$ feather meal, replacing finely ground corn.

$330 / 0=30 \%$ corn bran in diet. A different supplement was fed at 6\% diet DM in replacement of DRC for the first phase of finishing Exp. 1 that contained $0.93 \%$ urea, $1.42 \%$ blood meal, and $1.42 \%$ feather meal, replacing finely ground corn.

${ }^{4} 30 / 15=30 \%$ corn bran plus $15 \%$ steep in diet. A different supplement was fed at $6 \%$ diet DM in replacement of DRC for the first phase of finishing Exp. 1 that contained $0.27 \%$ urea, $0.35 \%$ blood meal, and $0.35 \%$ feather meal, replacing finely ground corn.

$545 / 15=45 \%$ corn bran plus $15 \%$ steep in diet. A different supplement was fed at $6 \%$ diet DM in replacement of DRC for the first phase of finishing Exp. 1 that contained no urea, $0.65 \%$ blood meal, and $0.65 \%$ feather meal, replacing finely ground corn.

${ }^{6}$ Premix contained $10 \% \mathrm{Mg}, 6 \% \mathrm{Zn}, 4.5 \% \mathrm{Fe}, 2 \% \mathrm{Mn}, 0.5 \% \mathrm{Cu}, 0.3 \% \mathrm{I}, 0.05 \% \mathrm{Co}$.

${ }^{7}$ Premix contained $176 \mathrm{~g}$ monensin $\cdot \mathrm{kg}^{-1}$ (Elanco Animal Health, Greenfield, IN).

${ }^{8}$ Premix contained $1,500 \mathrm{IU}$ vitamin A, 3,000 IU vitamin D, 3.7 IU vitamin $\mathrm{E} \cdot \mathrm{g}^{-1}$.

${ }^{9}$ Premix contained $88 \mathrm{~g}$ Tylosin $\cdot \mathrm{kg}^{-1}$ (Elanco Animal Health).

${ }^{10}$ Represented as \% of diet DM using analyzed nutrients for each ingredient.

${ }^{11} \mathrm{DIP}=$ degradable intake protein. The DIP for DRC, corn bran, steep, corn silage, molasses, urea, blood meal, and feather meal were $44.7 \%, 86 \%, 65 \%, 75 \%$, $100 \%, 287 \%, 25 \%$, and $30 \%$, respectively, of CP (DM; NRC, 1996).

${ }^{12}$ Represented as \% of diet DM using NRC (1996) values of each ingredient.

digestible portion. A first-order disappearance model was used to calculate the rates of ruminal DM and NDF degradation for DRC and corn bran, respectively. A natural logarithm of the percent of potentially degradable DM or NDF (corrected for extent hours) was regressed against time to calculate disappearance rates (slope of line, $\% / \mathrm{h}$ ).

Data were analyzed using the Proc Mixed procedure (SAS Inc., Cary, NC). Intake and total tract digestibil- ity were analyzed to determine differences among treatments and in situ disappearance was analyzed to test for interactions and main effects of treatment and time. Animal and period were used as random effects. Ruminal $\mathrm{pH}$ and VFA data were analyzed as repeated measures, with day and time repeated as appropriate. Toeplitz, ante-dependence, autoregressive, compound symmetry, and unstructured covariance models were tested, with 
the final structure selected based on the lowest Akaike information criterion. Probabilities of equal to or less than $\alpha(0.05)$ were considered significant.

\section{Feedlot Performance}

One hundred twenty-eight steer calves (initial BW = $314 \pm 12.7 \mathrm{~kg}$ ) were fed for $167 \mathrm{~d}$ (Exp. 2) and 256 yearling steers (initial BW $=366+13.9 \mathrm{~kg}$ ) were fed for $126 \mathrm{~d}$ (Exp. 3) to evaluate the effects of corn bran or corn bran in combination with steep on cattle performance and $\mathrm{N}$ losses from open feedlot pens. Experiments 2 and 3 were conducted from 5 November 2002 to 21 April 2003 and 6 May 2003 to 9 September 2003, respectively. At trial initiation, steers were weighed on 2 consecutive $\mathrm{d}$ after being limit fed a diet containing 50\% alfalfa hay and 50\% Sweet Bran (Cargill Inc.) at $2 \%$ of BW for $5 \mathrm{~d}$ to minimize gastrointestinal fill differences. Weights were averaged and used as initial weights. Steers were stratified by BW and assigned randomly to 1 of 4 dietary treatments ( 8 steers/pen; 4 pens/ treatment) in completely randomized designs.

Dietary treatments included a DRC-based diet, including 5\% molasses, 30/0, 30/15, and 45/15 (DM basis; Table 1). Inclusion of corn bran in $30 / 0$ replaced an equal amount of DRC, whereas inclusion of corn bran and steep in 30/15 and 45/15 replaced all molasses and some DRC. All diets contained 15\% corn silage and 5\% dry supplement. The dry supplement was formulated to provide $312 \mathrm{mg} /$ steer daily monensin and $90 \mathrm{mg} / \mathrm{steer}$ daily Tylosin (Elanco Animal Health, Greenfield, IN). To evaluate the effect of steep, corn bran and steep replaced DRC and molasses at $30 \%$ and $15 \%$, respectively (30/15). The 30/15 treatment was similar in composition to wet corn gluten feed (WCGF) in a study by Krehbiel et al. (1995). The final treatment included $45 \%$ and $15 \%$ corn bran and steep, respectively, to further increase the amount of OM (bran) in the manure.

Steer calves in Exp. 2 were implanted with Synovex$\mathrm{S}$ (Pfizer Animal Health, New York) on d 1 and steers in Exp. 2 and 3 were implanted with Revalor-S (Merck Animal Health, DeSoto, KS) on d 72 and 21, respectively. Steers were adapted to dietary treatments over a 21-d period. Roughage levels in the adaptation diets were reduced by decreasing alfalfa hay from 35 to 25 to $15 \% \mathrm{DM}$ and replacing this with DRC, and diets were fed for 7, 7, and $7 \mathrm{~d}$, respectively, whereas corn silage levels remained constant. Finishing diets were formulated to meet MP requirements, to minimize the amount of $\mathrm{N}$ excreted and $\mathrm{N}$ lost through volatilization (NRC, 1996). To accomplish this, steers in Exp. 2 received 2 protein supplements. During the first phase of this trial, steers were fed diets containing $6 \%$ dry supplement, which included blood meal and feather meal to meet MP needs. When steers reached approximately $450 \mathrm{~kg} \mathrm{BW}$ (d 66), a second phase was implemented by reducing the supplement to $5 \%$ of diet DM. In this supplement, finely ground corn replaced blood meal and feather meal. In Exp. 3, yearling steers were fed 1 supplement, which met MP requirements, throughout the trial.

Steers were visually appraised as being finished (e.g., $1.2 \mathrm{~cm}$ fat depth) and sent to a commercial abattoir (Tyson Foods, Inc, West Point, NE). On the day of harvest, HCW was recorded and LM area and 12th rib fat thickness were measured after a 24-h chill. Marbling and yield grade were determined by a USDA grader and recorded. Final BW, ADG, and G:F were calculated, based on $\mathrm{HCW}$ adjusted to a common dressing percentage of $63 \%$ to obtain an accurate final BW by minimizing errors associated with gut fill. Net energy calculations were performed using the procedures of Owens et al. (2002) to determine NEg values for corn bran, steep, and the diets.

Feed samples were collected monthly and analyzed for DM, OM, CP, and ash. Feed refusals were collected, weighed, subsampled, and analyzed for DM content, and stored for future analyses of CP and ash. Samples were oven dried at $60^{\circ} \mathrm{C}$ for $48 \mathrm{~h}$ to determine DM content of feeds and feed refusals.

\section{Nutrient Mass Balance}

A nutrient mass balance summary was conducted on each of the 2 finishing trials using procedures similar to those outlined in previous studies (Bierman et al., 1999; Erickson and Klopfenstein, 2001; Adams et al., 2004). Experiment 2 was conducted using 16 open-dirt feedlot pens with a stocking density of $32 \mathrm{~m}^{2}$ per steer. A cement apron extended the entire length of the feedbunk and $4.5 \mathrm{~m}$ into the pen from the edge of the feedbunk. All pens were separated with a fenceline on the mound and 1 at the back of the pen. The pen design was similar to that documented by Bierman et al. (1999). Experiment 3 was conducted using 24 open-dirt feedlot pens, in which 16 of the pens were the same pens used in Exp. 1. Pen design was similar to Exp. 1.

Seven earthen retention ponds, constructed of soil, were used to collect runoff from 12 of the feedlot pens. Due to the set-up of the feedlot, only 12 pens had retention ponds available to collect runoff. When rainfall events occurred, runoff was drained through a polyvinyl chloride pipe, sampled, and quantified, using an ISCO model 4230 air-bubble flow meter (ISCO, Lincoln, NE). Samples of the effluent were frozen at $-4^{\circ} \mathrm{C}$ for later analysis. Runoff samples were composited by weight for each pond based on amounts of runoff collected over the feeding period.

Approximately every $2 \mathrm{wk}$, fresh fecal samples (soil free) were taken randomly from the pen floor surface throughout each trial, with 2 samples per pen. Fecal samples were frozen $\left(-4^{\circ} \mathrm{C}\right)$ for subsequent analysis of 
$\mathrm{N}$ concentration. Samples were averaged across time for 1 measurement per pen over the entire experiment. Pens were cleaned approximately every $28 \mathrm{~d}$ during Exp. 2 and every $42 \mathrm{~d}$ during Exp. 3. Manure was scraped from pen floors and piled on the cement apron. As manure was removed from the pile, samples were obtained. Total manure was then weighed (as-is) and piled in windrows in a compost yard. Composting of manure was conducted similar to the procedures outlined by Adams et al. (2004) and Farran et al. (2006). Windrows were separated by dietary treatment and this process was considered finished when windrows did not produce heat 2 to $7 \mathrm{~d}$ after turning. After composting, a random sample was taken every $3 \mathrm{~m}$ on both sides of the compost windrow. These samples were then composited and sampled to obtain 1 representative sample per dietary treatment. Compost samples were sent to a commercial lab for further analysis of DM, OM, N, P, and ash content.

Fecal and manure samples were freeze dried using a Virtis Freezemobile model 25 SL (Virtis, Gardiner, NY) to avoid any $\mathrm{N}$ losses that may occur during the oven drying process. Samples were ground through a 1-mm Wiley Mill (Arther H. Thomas Co.) screen and composited by pen on an equal dry weight basis. Organic matter was determined after the ashing process (AOAC, 1999; method 942.05) for the soil, manure, and fecal composites. All soil, fecal, manure, and runoff samples were analyzed for total $\mathrm{N}$ percentage using the combustion method (AOAC, 1999; method 990.03). The runoff $\mathrm{N}$ amounts for each treatment pen were averaged and this average was used to account for $\mathrm{N}$ runoff from pens without retention ponds when total $\mathrm{N}$ losses were assessed. These data were not included in runoff $\mathrm{N}$ analysis.

Nitrogen intake was calculated based on analyzed dietary $\mathrm{N}$ content, multiplied by DMI, and corrected for $\mathrm{N}$ in feed refusals. Nitrogen retained by the steers was calculated using the net energy and protein equations listed in NRC (1996). Fecal N was determined using the DM digestibility numbers calculated in the metabolism study. Total $\mathrm{N}$ excretion (urinary plus fecal) was determined by subtracting $\mathrm{N}$ retention from $\mathrm{N}$ intake. Total $\mathrm{N}$ lost was calculated by subtracting manure $\mathrm{N}$ and runoff $\mathrm{N}$ from $\mathrm{N}$ excretion. Calculations for DM and OM excretion were determined using the DM and OM digestibility percentages obtained from the metabolism trial and actual DMI. Organic matter balance was calculated similar to that of $\mathrm{N}$ balance and both are represented on a kilogram/steer basis. Nitrogen lost on a percentage basis was calculated as $\mathrm{N}$ lost divided by $\mathrm{N}$ excretion. The $\mathrm{C}$-to- $\mathrm{N}$ ratio of manure was determined by multiplying the amount of manure OM by 0.49 (assuming OM contains $49 \% \mathrm{C}$ ) and dividing by the amount of $\mathrm{N}$ in manure (Nelson and Sommers, 1982).
Cattle performance, carcass characteristics, and nutrient mass balance data were analyzed as completely randomized designs, with pen as the experimental unit, using the Proc Mixed procedure of SAS. A protected F-test was used to determine treatment differences with mean separation using a Bonferroni $t$ test. Probabilities of equal to or less than $\alpha(0.05)$ were considered significant. Tendencies will be discussed when probabilities are between 0.05 and 0.10 .

\section{RESULTS AND DISCUSSION}

\section{Metabolism Study}

Dry matter intake was not significantly different among treatments $(11.4 \mathrm{~kg} / \mathrm{d}, P=0.56$; Table 2$)$. However, cattle fed the corn bran-based diets consumed more feed numerically. This effect may have not been detected statistically due to a small number of observations and/or individual steer DMI variation. Previous research has found differing DMI results in metabolism experiments. Bierman et al. (1999) observed no DMI differences between feeding $41.5 \%$ WCGF and a predominately corn diet, but Montgomery et al. (2004) observed greater DMI for cattle fed 40\% WCGF. Dietary treatment also had no effect on meal size, time spent eating, or meals consumed per day (data not presented). Even though the 30/15 and 45/15 diets appeared to be physically bulky, they did not increase the meal size or time spent eating. Total tract DM digestibility was greater for heifers fed $\mathrm{CON}$ than the by-product diets (79.0\% vs. $73.0 \%, P<0.01)$, as was OM digestibility $(80.2 \%$ vs. $74.6 \%, P<0.01)$. This was similar to Scott et al. (1998) who observed decreased DM digestibility when feeding $15 \%$ corn bran compared with a corn-only diet. Adding steep to corn bran in diets $30 / 15$ or $45 / 15$ provided no improvement in DM or OM digestibility, compared with including only corn bran, and remained less than the CON diet. This is different from Scott et al. (1998) who observed increased DM digestibility for cattle consuming diets containing $15 \%$ or $30 \%$ steep added to $15 \%$ corn bran, compared with $15 \%$ corn bran alone (Scott et al., 1998). Although the current study evaluated corn bran and steep alone, or in combination, comparisons can be made to WCGF. The results observed from feeding 40\% (Montgomery et al., 2004) and 41.8\% (Bierman et al., 1999) WCGF in corn diets were also different compared with a corn-based control diet, as DM digestibility decreased and OM digestibility increased, respectively. Although DM and OM digestibility were lower for the by-product diets than the CON diet, cattle consumed numerically more DM on these by-product diets and thus amount of digestible DM and OM were similar $(P \geq 0.90)$. Digestibility of NDF was greater $(P$ 
Table 2. Diet digestibility and in situ disappearance rates of dry-rolled corn and corn bran incubated in heifers fed corn bran in combination with steep in the metabolism study (Exp. 1)

\begin{tabular}{|c|c|c|c|c|c|c|}
\hline \multirow[b]{2}{*}{ Item } & \multicolumn{6}{|c|}{ Treatment $^{1}$} \\
\hline & $\mathrm{CON}$ & $30 / 0$ & $30 / 15$ & $45 / 15$ & SEM & $P$-value \\
\hline \multicolumn{7}{|l|}{ Total tract digestibility } \\
\hline DM intake, $\mathrm{kg}$ & 10.8 & 11.7 & 11.5 & 11.4 & 0.6 & 0.56 \\
\hline DM digested, $\mathrm{kg}^{2}$ & 8.53 & 8.62 & 8.37 & 8.28 & 0.45 & 0.90 \\
\hline DM digestibility, \% & $79.0^{\mathrm{a}}$ & $73.7^{\mathrm{b}}$ & $72.8^{\mathrm{b}}$ & $72.6^{\mathrm{b}}$ & 1.5 & 0.03 \\
\hline OM intake, $\mathrm{kg}$ & 10.0 & 10.9 & 10.7 & 10.6 & 0.6 & 0.56 \\
\hline OM digested, $\mathrm{kg}^{3}$ & 8.02 & 8.18 & 7.96 & 7.88 & 0.45 & 0.95 \\
\hline OM digestibility, \% & $80.2^{\mathrm{a}}$ & $75.0^{\mathrm{b}}$ & $74.4^{b}$ & $74.4^{\mathrm{b}}$ & 1.5 & 0.03 \\
\hline NDF intake, $\mathrm{kg}$ & $1.40^{\mathrm{c}}$ & $3.86^{\mathrm{b}}$ & $3.69^{\mathrm{b}}$ & $4.68^{\mathrm{a}}$ & 0.19 & $<0.01$ \\
\hline NDF digestibility, \% & $53.8^{\mathrm{a}}$ & $66.5^{\mathrm{b}}$ & $61.9^{\mathrm{b}}$ & $64.5^{\mathrm{b}}$ & 1.8 & $<0.01$ \\
\hline \multicolumn{7}{|c|}{ In situ disappearance rates } \\
\hline $\mathrm{DMd}^{4}$ (corn) & 5.09 & 4.49 & 4.54 & 4.76 & 0.46 & 0.78 \\
\hline $\mathrm{DMd}^{4}$ (bran) & 2.36 & 2.49 & 2.84 & 3.19 & 0.66 & 0.81 \\
\hline $\mathrm{NDFd}^{5}$ (bran) & 0.72 & 1.61 & 1.49 & 1.89 & 0.39 & 0.23 \\
\hline
\end{tabular}

${ }^{\mathrm{a}-\mathrm{c}}$ Means in the same row without a common superscript differ $(P<0.05)$.

${ }^{1} \mathrm{CON}=0 \%$ by-product, $30 / 0=30 \%$ corn bran, $30 / 15=30 \%$ corn bran plus $15 \%$ steep, $45 / 15=45 \%$ corn bran plus $15 \%$ steep (DM basis). Inclusion of byproducts replaced dry-rolled corn.

${ }^{2} \mathrm{DM}$ digested $=\mathrm{DMI} \cdot \mathrm{DM}$ digestibility.

${ }^{3} \mathrm{OM}$ digested $=\mathrm{OMI} \cdot \mathrm{OM}$ digestibility.

${ }^{4} \mathrm{DMd}=\mathrm{DM}$ disappearance rate calculated as $\% / \mathrm{h}$ of corn or bran incubated in steers fed the different treatment diets.

${ }^{5} \mathrm{NDFd}=\mathrm{NDF}$ disappearance rate calculated as $\% / \mathrm{h}$ of bran incubated in steers fed the different treatment diets.

$<0.01$ ) for the corn bran and steep diets, compared with the CON diet. Montgomery et al. (2004) also observed increased NDF digestibility when feeding $40 \%$ WCGF compared with corn. The improvement in NDF digestibility is likely due to a $2.7-\mathrm{kg}$ increase in NDF intake and decrease in starch intake. The NDF present in the rumen is different as the by-product diets contained considerably more corn bran, which increased dietary NDF and also the type of NDF being fed, particularly compared with the CON diet. Therefore, the improvement in NDF digestibility for feeding these by-product diets is likely due to the large proportion of digestible fiber coming from corn bran.

The NDF content of corn bran was $72.9 \%$ in this experiment, which is similar to DeHaan (1983) and Scott et al. (1998), who reported 69 to 80\% NDF. Digestion of corn bran NDF in in situ bags can be an indication of rumen fiber digestion as impacted by diet. This digestion measure (i.e., in situ NDF digestibility of corn bran) was greater for cattle fed the corn bran diets compared with $\mathrm{CON}$ at 48 and $96 \mathrm{~h}(P<0.01$; Fig. 1). However, the digestion rates for DRC and corn bran were not different ( $P \geq 0.23$; Table 2$)$. Rate of corn bran NDF digestion was numerically greater when it was incubated in the by-product-fed cattle compared with CON fed cattle. Although not statistically different, a greater extent (and possibly rate) of in situ corn bran NDF digestion can be explained by greater rumen $\mathrm{pH}$, presumably due to less dietary starch in by-product diets. Greater rumen $\mathrm{pH}$ can improve fiber digestion (Van Soest, 1994).

Total VFA concentrations were not different among treatments $(P=0.07$; Table 3$)$. The CON diet had the lowest acetate:propionate ratio, whereas the 45/15 diet had the greatest acetate:propionate ratio. The molar proportion of acetate was greater $(P<0.01)$ in the rumen of cattle fed the $45 / 15 \operatorname{diet}(58.2 \mathrm{~mol} / 100 \mathrm{~mol}$, Table 3$)$ compared with the CON diet $(53.1 \mathrm{~mol} / 100 \mathrm{~mol})$, and the other diets were numerically intermediate. This in-

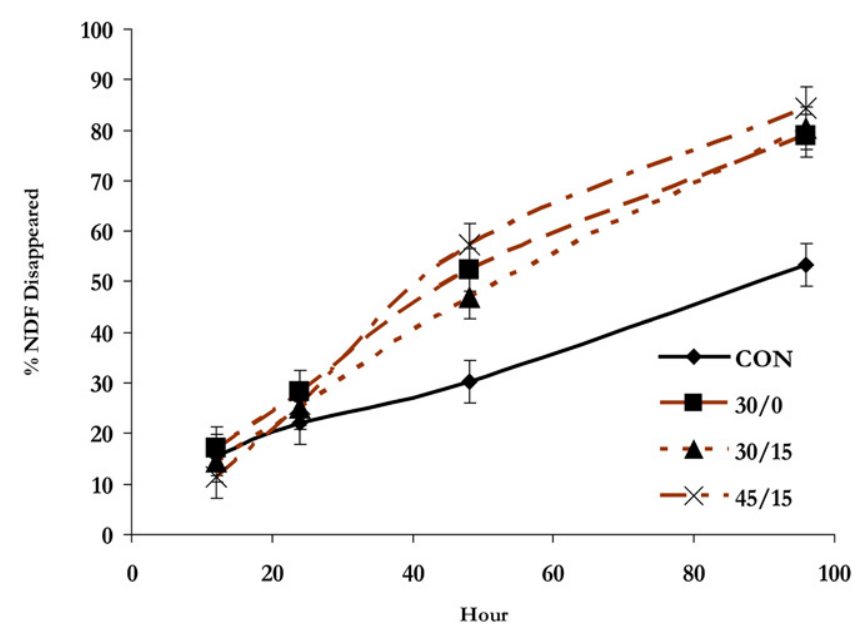

Figure 1. Corn bran NDF disappearance at 12, 24, 48, and $96 \mathrm{~h}$ and incubated within each dietary treatment. $\mathrm{CON}=0 \%$ by-product; $30 / 0=30 \%$ corn bran; $30 / 15=30 \%$ corn bran plus $15 \%$ steep; $45 / 15=45 \%$ corn bran plus $15 \%$ steep (DM basis). 
Table 3. Ruminal $\mathrm{pH}$ and VFA concentrations for heifers fed corn bran in combination with steep in the metabolism study (Exp. 1)

\begin{tabular}{|c|c|c|c|c|c|c|}
\hline \multirow[b]{2}{*}{ Item } & \multicolumn{6}{|c|}{ Treatment $^{1}$} \\
\hline & $\mathrm{CON}$ & $30 / 0$ & $30 / 15$ & $45 / 15$ & SEM & $P$-value \\
\hline$\overline{\text { Average } \mathrm{pH}}$ & $5.76^{\mathrm{c}}$ & $5.90^{\mathrm{b}}$ & $5.94^{\mathrm{b}}$ & $6.02^{\mathrm{a}}$ & 0.05 & $<0.01$ \\
\hline Total VFA, mM & 109.4 & 88.2 & 103.7 & 87.7 & 9.1 & 0.07 \\
\hline Acetate:propionate & $2.09^{\mathrm{c}}$ & $2.25^{\mathrm{b}}$ & $2.30^{\mathrm{b}}$ & $2.52^{\mathrm{a}}$ & 0.21 & $<0.01$ \\
\hline Acetate $^{2}$ & $53.1^{\mathrm{c}}$ & $56.2^{\mathrm{b}}$ & $54.9^{\mathrm{bc}}$ & $58.2^{\mathrm{a}}$ & 1.6 & $<0.01$ \\
\hline Propionate $^{2}$ & $27.8^{\mathrm{a}}$ & $25.1^{\mathrm{b}}$ & $24.3^{\mathrm{b}}$ & $24.6^{\mathrm{b}}$ & 1.7 & 0.04 \\
\hline Butyrate $^{2}$ & 14.5 & 14.7 & 14.0 & 12.7 & 1.1 & 0.17 \\
\hline
\end{tabular}

${ }^{\mathrm{a}-\mathrm{c}}$ Means in the same row without a common superscript differ $(P<0.05)$.

${ }^{1} \mathrm{CON}=0 \%$ by-product, $30 / 0=30 \%$ corn bran, $30 / 15=30 \%$ corn bran plus $15 \%$ steep, $45 / 15=45 \%$ corn bran plus $15 \%$ steep (DM basis). Inclusion of byproducts replaced dry-rolled corn.

${ }^{2}$ Represented as mol/100mol.

crease in acetate concentration suggests that fiber digestion was being promoted. Including corn bran and steep in these diets decreased $(P<0.01)$ the molar proportions of propionate compared with CON. This is likely because there was less starch in the by-product diets that would promote more propionate production. This decrease in propionate, when including steep in the diet, is different from Scott et al. (1998), who observed that as steep inclusion increased, propionate also increased. Steep can contain 25\% lactic acid (Blanchard, 1992) and it was suggested that because of the increased amount of lactic acid provided by steep, propionate production would also increase. However, in the current study, effects of steep may have been diluted due to the amount of corn bran in the diet.

Feeding diets that included by-products $(30 / 0$, $30 / 15$, and $45 / 15$ ) resulted in a greater ruminal average $\mathrm{pH}$ (5.95) than CON (5.76; $P<0.01$; Table 3$)$. Although steep contains some lactic acid, ruminal $\mathrm{pH}$ for cattle fed 30/15 did not decrease compared with feeding 30/0 (5.94 vs. 5.90, respectively, $P=0.15$ ). Including additional bran in the $45 / 15$ diet resulted in greater rumen $\mathrm{pH}$ than feeding all of the other diets $(P<0.01)$. These results support the concept that feeding gluten feed helps minimize the effects of acidosis. Montgomery et al. (2004) also observed increased rumen $\mathrm{pH}$ when feeding 40\% WCGF compared with a steam-flaked corn diet. Krehbiel et al. (1995) demonstrated that acidosis load can be reduced with the feeding of WCGF, via reduction of the starch load in the rumen. The 30/15 diet would be similar in composition to the WCGF fed by Krehbiel et al. (1995). They ruminally dosed cattle with $7.9 \mathrm{~kg}$ of WCGF and observed a decrease in the area of time spent with a $\mathrm{pH}<5.6$ compared with dosing with DRC, thus reducing ruminal acidosis with WCGF. The reduction of starch load and increase in rumen $\mathrm{pH}$ for cattle fed the by-product diets in the current study may explain the increased digestion of DRC and corn bran in in situ bags.

\section{Feedlot Performance}

Dry matter intake tended to increase $(P=0.06)$ in Exp. 2 (Table 4$)$ and was statistically greater $(P<0.01)$ in Exp. 3 (Table 5) for steers consuming the by-product diets compared with CON. These DMI were 0.2 to 0.9 $\mathrm{kg} / \mathrm{d}$ greater when cattle were fed by-products compared with CON within the same experiment. Including corn bran in diets increases the fiber content of the diets. Increasing fiber content in the diet may increase DMI as shown by Galyean and Defoor (2003). Therefore, it is logical that including corn bran, which contains $80 \%$ NDF, would increase DMI. Adams et al. (2004) also observed increased DMI when corn bran was added to feedlot cattle diets. Several other studies have observed increased DMI when feeding WCGF compared with corn (Firkins et al., 1985; Macken et al., 2004; and Farran et al., 2006). Cattle may consume more DM with increasing dietary fiber from corn bran or WCGF, due to greater rumen $\mathrm{pH}$ (Krehbiel et al., 1995).

Average daily gain was not significantly different among treatments in Exp. $2(P=0.22)$ but tended to increase in Exp. 3 for steers fed diets containing steep (30/15 and 45/15; $P=0.07)$. Inconsistent results were also observed for G:F as Exp. 2 results were not different $(P=0.56)$ among treatments, but $\mathrm{G}: \mathrm{F}$ was reduced (7.5\% decrease) in Exp. 3 for steers fed corn bran with no steep $(30 / 0 ; P=0.05)$. The data from Exp. 3 agree with the reduced G:F observed when feeding corn bran in diets in previous studies (Erickson and Klopfenstein, 2001; Adams et al., 2004). Feed efficiency for cattle fed $30 / 15$ or $45 / 15$ were greater than cattle fed $30 / 0$ and were similar to cattle fed CON. This calculated into a $6.25 \%$ improvement when steep was added to corn bran (30/15). The greater ADG and G:F for steers fed steep in Exp. 3 agrees with Scott et al. (1997), who suggested steep has a greater energy content than the DRC it replaces. Including WCGF in diets increased ADG compared with the corn control diet as shown by Firkins et 
Table 4. Performance, carcass characteristics, and $\mathrm{N}$ mass balance for steers fed corn bran in combination with steep for $167 \mathrm{~d}$ in the winter/spring months (Exp. 2)

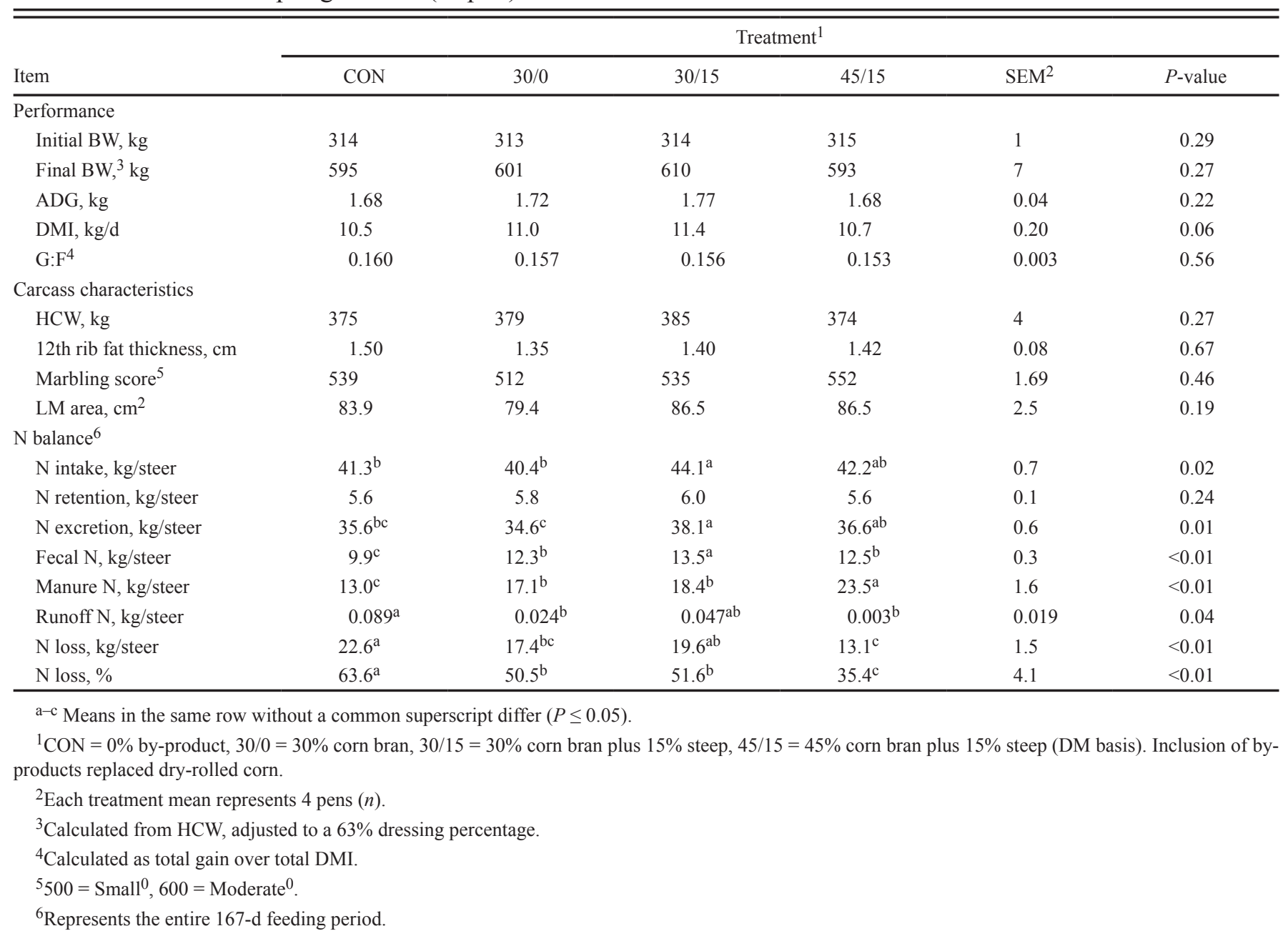

al. (1985) and Richards et al. (1998). However, other research has shown no ADG or G:F differences in feeding WCGF compared with a corn-only diet (Macken et al., 2004). These data support the 1 to $15 \%$ greater energy values reported for WCGF relative to DRC. Stock et al. (2000) suggested that WCGF provides a highly fermentable fiber that can help minimize the effects of acidosis.

The NEg for corn bran was calculated at $84.0 \%$ and $66.1 \%$ the value of DRC for Exp. 2 and 3, respectively. Adding steep in the 30/15 diet in Exp. 3 improved NEg by $25.3 \%$ when compared with the $30 / 0$ diet, suggesting a $2.9 \%$ greater energy value than the DRC it replaced. These data support the theory that steep helps maintain cattle performance when bran is included in the diet.

No differences $(P \geq 0.11)$ were observed for any carcass measurement in Exp. 2 or 3. This implies that cattle can be finished on diets containing moderate amounts (30 to $60 \%$ of diet DM) of corn bran and steep, and result in similar HCW, 12th rib fat thickness, marbling score, and LM area. This is different than Adams et al. (2004), who had to feed cattle consuming 30\% corn bran an additional $14 \mathrm{~d}$ to reach an equivalent carcass endpoint compared with a corn-only diet.

\section{Nutrient Mass Balance}

Organic matter intake was not different in Exp. 2 (average $=10.4 \mathrm{~kg} / \mathrm{d} ; P=0.11$ ), but greater OM intakes $(P<0.01)$ were observed for steers consuming the byproduct diets in Exp. $3(11.0 \mathrm{~kg} / \mathrm{d}$ for by-product diets and $10.4 \mathrm{~kg} / \mathrm{d}$ for $\mathrm{CON}$ ), particularly due to differences in DMI. Due to OM digestibility differences from the metabolism trial and greater DMI for steers in Exp. 3, more OM was excreted from steers fed the by-product diets (average $=372 \mathrm{~kg} ; P<0.01)$ compared with CON $(279 \mathrm{~kg})$. Excretion of OM in Exp. 2 was also greater for steers consuming the by-product diets (average $=463$ $\mathrm{kg} ; P<0.01)$ due to decreased diet digestibility compared with CON $(351 \mathrm{~kg})$.

In Exp. 2, manure OM increased 54\% for the 30/0 and 30/15 treatments, compared with $\mathrm{CON}(P<0.01$; Table 6), and manure OM increased $36 \%$ more for steers fed the 45/15 diet. In Exp. 3, manure OM was again 
Table 5. Performance, carcass characteristics, and $\mathrm{N}$ mass balance for steers fed corn bran in combination with steep for $126 \mathrm{~d}$ in the summer months (Exp. 3)

\begin{tabular}{|c|c|c|c|c|c|c|}
\hline \multirow[b]{2}{*}{ Item } & \multicolumn{6}{|c|}{ Treatment $^{1}$} \\
\hline & $\mathrm{CON}$ & $30 / 0$ & $30 / 15$ & $45 / 15$ & SEM & $P$-value \\
\hline \multicolumn{7}{|l|}{ Performance } \\
\hline Initial BW, kg & 367 & 366 & 365 & 367 & 1 & 0.54 \\
\hline Final $\mathrm{BW},{ }^{3} \mathrm{~kg}$ & 567 & 564 & 580 & 575 & 5 & 0.15 \\
\hline $\mathrm{ADG}, \mathrm{kg}$ & 1.59 & 1.57 & 1.71 & 1.65 & 0.04 & 0.07 \\
\hline DMI, kg/d & $10.9^{\mathrm{b}}$ & $11.6^{\mathrm{a}}$ & $11.8^{\mathrm{a}}$ & $11.5^{\mathrm{a}}$ & 0.11 & $<0.01$ \\
\hline G:F $F^{4}$ & $0.146^{\mathrm{a}}$ & $0.135^{\mathrm{b}}$ & $0.144^{\mathrm{a}}$ & $0.143^{\mathrm{a}}$ & 0.003 & 0.05 \\
\hline \multicolumn{7}{|l|}{ Carcass characteristics } \\
\hline $\mathrm{HCW}, \mathrm{kg}$ & 357 & 356 & 366 & 362 & 7 & 0.15 \\
\hline 12th rib fat thickness, $\mathrm{cm}$ & 1.22 & 1.32 & 1.27 & 1.24 & 0.08 & 0.74 \\
\hline Marbling score ${ }^{5}$ & 500 & 501 & 515 & 484 & 0.85 & 0.11 \\
\hline LM area, $\mathrm{cm}^{2}$ & 88.4 & 87.4 & 89.4 & 89.8 & 1.0 & 0.34 \\
\hline \multicolumn{7}{|l|}{$\mathrm{N}$ balance ${ }^{6}$} \\
\hline $\mathrm{N}$ intake, $\mathrm{kg} /$ steer & $34.0^{\mathrm{c}}$ & $37.7^{\mathrm{a}}$ & $36.7^{\mathrm{b}}$ & $36.2^{\mathrm{b}}$ & 0.3 & $<0.01$ \\
\hline $\mathrm{N}$ retention, $\mathrm{kg} /$ steer & $5.06^{\mathrm{b}}$ & $4.96^{\mathrm{b}}$ & $5.42^{\mathrm{a}}$ & $5.22^{\mathrm{ab}}$ & 0.11 & 0.05 \\
\hline $\mathrm{N}$ excretion, $\mathrm{kg} /$ steer & $29.0^{\mathrm{c}}$ & $32.7^{\mathrm{a}}$ & $31.3^{\mathrm{b}}$ & $31.0^{\mathrm{b}}$ & 0.3 & $<0.01$ \\
\hline Fecal $\mathrm{N}, \mathrm{kg} /$ steer & $6.72^{\mathrm{c}}$ & $9.21^{\mathrm{b}}$ & $9.93^{\mathrm{a}}$ & $9.78^{\mathrm{a}}$ & 0.13 & $<0.01$ \\
\hline Manure $\mathrm{N}, \mathrm{kg} /$ steer & $10.1^{\mathrm{b}}$ & $13.5^{\mathrm{a}}$ & $13.0^{\mathrm{a}}$ & $13.2^{\mathrm{a}}$ & 0.7 & 0.01 \\
\hline Runoff $\mathrm{N}, \mathrm{kg} /$ steer & 1.04 & 0.75 & 1.47 & 0.67 & 0.09 & 0.09 \\
\hline $\mathrm{N}$ loss, $\mathrm{kg} /$ steer & 17.8 & 18.5 & 16.8 & 17.1 & 0.8 & 0.44 \\
\hline $\mathrm{N}$ loss, $\%$ & 61.6 & 56.5 & 53.7 & 55.2 & 2.5 & 0.16 \\
\hline
\end{tabular}

${ }^{\mathrm{a}-\mathrm{c}}$ Means in the same row without a common superscript differ $(P \leq 0.05)$.

${ }^{1} \mathrm{CON}=0 \%$ by-product, $30 / 0=30 \%$ corn bran, $30 / 15=30 \%$ corn bran plus $15 \%$ steep, $45 / 15=45 \%$ corn bran plus $15 \%$ steep (DM basis). Inclusion of byproducts replaced dry-rolled corn.

${ }^{2}$ Each treatment mean represents 4 pens $(n)$.

${ }^{3}$ Calculated from $\mathrm{HCW}$, adjusted to a $63 \%$ dressing percentage.

${ }^{4}$ Calculated as total gain over total DMI.

${ }^{5} 400=$ Slight $^{0}, 500=$ Small $^{0}$.

${ }^{6}$ Represents the entire 126-d feeding period.

greater for the by-product treatments compared with $\operatorname{CON}(P<0.01)$.

Due to the increase in DMI for steers fed the byproduct diets $(30 / 0,30 / 15$, and $45 / 15)$ compared with CON diets, $\mathrm{N}$ intakes were greater for steers consuming the $30 / 15$ diet in Exp. $2(P=0.02)$ and steers consuming all of the by-product diets in Exp. $3(P<0.01)$. Nitrogen retention was not different in Exp. $2(P=0.24$; Table 4$)$; however, yearling steers in Exp. 3 retained less $\mathrm{N}$ on the CON and 30/0 treatments than on the 30/15 treatment $(P=0.05$; Table 5$)$. Nitrogen retention was decreased for steers consuming CON and 30/0 in Exp. 3 due to reduced $\mathrm{ADG}$ and $\mathrm{BW}$. The $\mathrm{N}$ retention results were similar to Erickson and Klopfenstein (2001), but they were numerically greater than those reported by Adams et al. (2004).

Nitrogen excretion was greater for steers fed the by-product diets in Exp. 2 and $3(P \leq 0.01)$, due to increased $\mathrm{N}$ intakes. This agrees with the predictions of NRC (1996) that $>85 \%$ of dietary $\mathrm{N}$ is excreted. Fecal N increased for cattle fed by-product diets in both experiments $(P<0.01)$. In Exp. 2, feeding the $30 / 0$ and $30 / 15$ diets increased the amount of fecal $\mathrm{N}$ by $24.2 \%$ and $36.4 \%$, respectively, greater than CON. In Exp. 3, fecal $\mathrm{N}$ also increased for steers fed $30 / 0,30 / 15$, and $45 / 15$, by $37.1 \%, 47.8 \%$, and $45.5 \%$, respectively. These data suggest that increasing dietary corn bran alters the route of $\mathrm{N}$ excretion proportionally to more $\mathrm{N}$ in feces and less $\mathrm{N}$ in urine, similar to Bierman et al. (1999).

In both experiments, manure $\mathrm{N}$ content was greater for steers fed the by-product diets than manure for steers fed CON $(P \geq 0.01)$. In Exp. 2, feeding CON resulted in the greatest $\mathrm{N}$ loss, represented as kilograms per steer $(\mathrm{kg} / \mathrm{steer})$ and percentage of $\mathrm{N}$ excretion $(63.6 \% ; P<$ $0.01)$. Including corn bran with and without steep in the $30 / 0$ and 30/15 diets resulted in decreased $\mathrm{N}$ loss $(\mathrm{kg} /$ steer; $23.0 \%$ and $13.3 \%$, respectively) than CON. Loss of $\mathrm{N}$ was decreased more by feeding $45 / 15(24.7 \%$ and $33.2 \%$ ) than $30 / 0$ and $30 / 15$, respectively. Amount of $\mathrm{OM}$ removed in the manure followed this trend in $\mathrm{N}$ loss in Exp. 2 as steers fed CON had the lowest amount of OM removed (274 kg/steer). Steers fed 45/15 had the greatest amount of OM removed $(575 \mathrm{~kg} / \mathrm{steer})$ and steers fed $30 / 0$ and $30 / 15$ were intermediate $(P<0.01$; 
Table 6. Nutrient composition for manure and compost for Exp. 2 (winter/spring) and Exp. 3 (summer)

\begin{tabular}{|c|c|c|c|c|c|c|}
\hline Item & \multicolumn{6}{|c|}{ Treatment ${ }^{1}$} \\
\hline \multicolumn{7}{|l|}{ Exp. 1} \\
\hline DM removed, $\mathrm{kg} /$ steer & $1,079^{\mathrm{b}}$ & $1,143^{b}$ & $1,239^{\mathrm{b}}$ & $1,749^{\mathrm{a}}$ & 137 & 0.02 \\
\hline OM removed, $\mathrm{kg} /$ steer & $274^{\mathrm{c}}$ & $420^{\mathrm{b}}$ & $424^{b}$ & $575^{\mathrm{a}}$ & 38 & $<0.01$ \\
\hline Nitrogen, $\mathrm{kg} /$ steer & 6.84 & 8.00 & 7.69 & 11.30 & 1.1 & 0.06 \\
\hline$\% \mathrm{~N}$ recovered & 51.6 & 47.1 & 42.4 & 47.5 & 4.8 & 0.61 \\
\hline $\mathrm{OM}, \mathrm{kg} / \mathrm{steer}$ & 120 & 137 & 135 & 186 & 18 & 0.12 \\
\hline$\%$ OM removed & 43.5 & 33.0 & 32.6 & 32.0 & 4.4 & 0.25 \\
\hline \multicolumn{7}{|l|}{ Exp. 2} \\
\hline \multicolumn{7}{|l|}{ Compost } \\
\hline $\mathrm{N}, \mathrm{kg} /$ steer & $5.66^{\mathrm{b}}$ & $8.47^{\mathrm{a}}$ & $7.40^{\mathrm{ab}}$ & $9.38^{\mathrm{a}}$ & 0.86 & 0.04 \\
\hline$\% \mathrm{~N}$ recovered & 55.7 & 62.7 & 56.4 & 70.4 & 4.8 & 0.14 \\
\hline $\mathrm{OM}, \mathrm{kg} / \mathrm{steer}$ & $89^{\mathrm{b}}$ & $126^{\mathrm{ab}}$ & $113^{\mathrm{ab}}$ & $149^{\mathrm{a}}$ & 13 & 0.04 \\
\hline$\%$ OM removed & 49.3 & 47.5 & 43.3 & 53.5 & 4.5 & 0.47 \\
\hline
\end{tabular}

Table 6). This agrees with the correlation calculated by Bierman et al. (1999), in which a linear relationship resulted between the amount of OM on the pen floor and $\mathrm{N}$ trapped in the manure $\left(R^{2}=0.90\right)$. This is also similar to previous research that reported as dietary digestibility decreases, the amount of $\mathrm{OM}$ on the pen floor and $\mathrm{N}$ recovery in the manure increases (Erickson et al., 2002; Adams et al., 2004).

Although manure $\mathrm{N}$ increased $(P=0.01)$ when byproducts were fed in Exp. 3, no differences $(P \geq 0.16)$ in $\mathrm{N}$ loss were observed among treatments (averaging $56.8 \%$ ). The amount of $\mathrm{OM}$ removed from the manure also increased $(P<0.01)$ in this summer experiment when by-products were fed. Therefore, the theory that increasing $\mathrm{OM}$ in the manure decreases $\mathrm{N}$ volatilization does not appear to hold true during summer months. Erickson and Klopfenstein (2010) suggested that N volatilization losses are rapid and large during warm, summer months and extra OM has little value in trapping more manure N. Adams et al. (2004) also observed a decrease in $\mathrm{N}$ loss during winter months, but no differences resulted during summer.

These trials suggest that fibrous feedstuffs (i.e., corn bran) can be added to diets and increase OM excretion that can trap $\mathrm{N}$ in manure and decrease $\mathrm{N}$ volatilization. However, $\mathrm{N}$ loss was only decreased during the winter feeding period. The seasonal response is similar to pre- vious observations using corn bran where $\mathrm{N}$ losses were decreased in winter but not in the summer (Erickson and Klopfenstein, 2001; Adams et al., 2004). Using corn bran in diets may provide an opportunity to minimize $\mathrm{N}$ volatilization, but cattle performance can be hindered. This study suggested that using steep in combination with corn bran can maintain decreased $\mathrm{N}$ volatilization and still maintain cattle performance, compared with CON.

The C-to-N ratio in manure numerically increased in Exp. $2(P=0.18)$ and statistically increased in Exp. 3 $(P<0.01)$, when the by-product treatments were compared with CON. These data are supported by the result that more OM was removed from pens where steers were fed corn bran alone or in combination with steep. The increase in C-to-N ratio suggests that manure $\mathrm{N}$ was bound and in a more stable form; thus, less was available for volatilization. There is more $\mathrm{C}$ available in this manure for the microbial population to use, which would cause an increased need for $\mathrm{N}$. This can trap more $\mathrm{N}$ in the manure as microbial protein. Adams et al. (2004) suggested that OM produced by feeding corn bran was in a readily available form for the microbial population to use, compared with adding $\mathrm{OM}$ in the form of sawdust to the pen floor surface. Although more OM was removed from the pen floor when applying sawdust, there was no difference in 
the amount of $\mathrm{N}$ removed. This suggests that $\mathrm{C}$ from sawdust is not as readily available as $\mathrm{C}$ from corn bran.

Although the $\mathrm{C}$-to- $\mathrm{N}$ ratio was increased by feeding by-products in Exp. 3, the percent of $\mathrm{N}$ loss was not different. This is similar to findings by Adams et al. (2004), in which the C-to-N ratio was also increased by feeding corn bran; however, it did not reduce $\mathrm{N}$ losses during summer months, likely due to rapid $\mathrm{N}$ volatilization rates.

Although there were no differences in OM present in the compost for Exp. $2(P=0.12)$, greater OM amounts were present in the compost for steers fed the by-product diets compared with CON in Exp. $3(P=0.04)$. However, when these OM were represented as a percentage of initial manure amounts, no differences were observed among treatments in either experiment $(P \geq 0.25)$.

The amount of $\mathrm{N}$ in the compost tended to be greater in Exp. $2(P=0.06)$ and was greater in Exp. $3(P=0.04)$ for manure removed in pens where steers were fed the by-product diets, compared with CON. However, when percent $\mathrm{N}$ recovery in the compost was calculated based on initial $\mathrm{N}$ removed from the pens, there were no differences among dietary treatments in either experiment $(P \geq$ $0.14)$. Even though it was not significantly different, the $45 / 15$ treatment had numerically the greatest percent of $\mathrm{N}$ recovered $(70.4 \%)$, whereas the CON treatment had the lowest percent of $\mathrm{N}$ recovered in compost (55.7\%) in the summer experiment (Exp. 3). These data suggest that as more $\mathrm{OM}$ is present, more $\mathrm{N}$ is trapped in the compost. This theory is in agreement with a study by Adams et al. (2004), who suggested that feeding corn bran was a more effective tool for retaining $\mathrm{N}$ in the compost than adding sawdust as an OM source. As more $\mathrm{N}$ is retained in compost, the value of the compost as a fertilizer may increase. Compost also has more value than raw manure from the pen floor due to decreased moisture levels and a smaller, more uniform particle size (DeLuca and DeLuca, 1997).

\section{LITERATURE CITED}

Adams, J. R., T. B. Farran, G. E. Erickson, T. J. Klopfenstein, C. N. Macken, and C. B. Wilson. 2004. Effect of organic matter addition to the pen surface and pen cleaning frequency on nitrogen balance in open feedlots. J. Anim. Sci. 82:2153-2163.

AOAC. 1999. Official method of analysis. 16th ed. Assoc. Off. Anal. Chemists, Arlington, VA.

Association of Official Analytical Chemists. 1996. Official methods of analysis of AOAC International. 16th ed. 4th rev. P. Cunniff, editor. AOAC Int., Gaithersburg, MD.

Bierman, S., G. E. Erickson, T. J. Klopfenstein, R. A. Stock, and D. H. Shain. 1999. Evaluation of nitrogen and organic matter balance in the feedlot as affected by level and source of dietary fiber. J. Anim. Sci. 77:1645-1653.

Blanchard, P. H. 1992. Technology of corn wet milling and associated processes. Vol. 4. Industrial Chemistry Library, Elsevier, NY.
Cooper, R. J., T. J. Klopfenstein, R. A. Stock, C. T. Milton, D. W. Herold, and J. C. Parrott. 1999. Effects of imposed feed intake variation on acidosis and performance of finishing steers. J. Anim. Sci. 77:1093-1099.

DeHaan, K. A. 1983. Improving utilization of fiber and energy through the use of corn gluten feed and alkali compounds. PhD Diss. Univ. of Nebraska, Lincoln.

DeLuca, T. H., and D.K. DeLuca. 1997. Composting for feedlot manure management and soil quality. J. Prod. Agric. 10:235-241.

Erickson, G. E., and T. J. Klopfenstein. 2001. Nutritional methods to decrease $\mathrm{N}$ losses from open-dirt feedlots in Nebraska. Sci. World 1(S2):836-843.

Erickson, G. E., and T. J. Klopfenstein. 2010. Nutritional and management methods to decrease nitrogen losses from beef feedlots. J. Anim. Sci. 88:E172-E180.

Erickson, G. E., T. J. Klopfenstein, and C. Milton. 2002. Corn bran level in finishing diets and $\mathrm{N}$ losses from open-dirt pens. Nebraska Beef Rep. MP 79-A:54-57.

Erwin, E. S., G. J. Marco, and E. M. Emery. 1961. Volatile fatty acid analyses of blood and rumen fluid by gas chromatography. J. Anim. Sci. 44:1768-1771.

Farran, T. B., G. E. Erickson, T. J. Klopfenstein, C. N. Macken, and R. U. Lindquist. 2006. Wet corn gluten feed and alfalfa hay levels in dry-rolled corn finishing diets: Effects on finishing performance and feedlot nitrogen mass balance. J. Anim. Sci. 84:1205-1214.

Firkins, J. L., L. L. Berger, and G. C. Fahey, Jr. 1985. Evaluation of wet and dry distillers grains and wet and dry corn gluten feeds for ruminants. J. Anim. Sci. 60:847-860.

Galyean, M. L., and P. J. Defoor. 2003. Effects of roughage source and level on intake by feedlot cattle. J. Anim. Sci. 81(E. Suppl. 2):E8-E16.

Krehbiel, C. R., R. A. Stock, D. W. Herold, D. H. Shain, G. A. Ham, and J. E. Carulla. 1995. Feeding wet corn gluten feed to reduce subacute acidosis in cattle. J. Anim. Sci. 73:2931-2939.

Macken, C. N., G. E. Erickson, T. J. Klopfenstein, and R. A. Stock. 2004. Effects of concentration and composition of wet corn gluten feed in steam-flaked corn-based finishing diets. J. Anim. Sci. 82:2718-2723.

Merchen, N. R. 1988. Digestion, absorption, and excretion in ruminants. In: D. C. Church, editor, The ruminant animal: Digestive physiology and nutrition. Waveland Press, Inc., Prospect Hills, IL.

Mobley, H. L., M. D. Island, and R. P. Hausinger. 1995. Molecular biology of microbial ureases. Microbiol. Rev. 59:451-480.

Montgomery, S. P., J. S. Drouillard, E. C. Titgemeyer, J. J. Sindt, T. B. Farran, J. N. Pike, C. M. Coetzer, A. M. Trater, and J. J. Higgins. 2004. Effects of wet corn gluten feed and intake level on diet digestibility and ruminal passage rate in steers. J. Anim. Sci. 82:3526-3536.

Nelson, D. W., and L. E. Sommers. 1982. Total carbon, organic carbon, and organic matter. In: A. L. Page, editor, Methods of soil analysis. Part 2. Chemical and microbiological properties. Agronomy Monograph 9.2, Madison, WI. p. 539-579.

NRC. 1996. Nutrient requirements of beef cattle. National Academy Press, Washington, DC.

Owens, F. N., D. S. Secrist, M. A. Hinds, and D. W. Rice. 2002. Methods for calculating diet energy values from feedlot performance of cattle. J. Anim. Sci. 80(Suppl. 1):273. (Abstr.)

Richards, C. J., R. A. Stock, T. J. Klopfenstein, and D. H. Shain. 1998. Effect of wet corn gluten feed, supplemental protein, and tallow on steer finishing performance. J. Anim. Sci. 76:421-428.

Scott, T., T. Klopfenstein, R. Stock, and R. Cooper. 1997. Evaluation of corn bran and corn steep liquor for finishing steers. Nebraska Beef Rep. MP 67A:72-74. 
Scott, T., T. J. Klopfenstein, R. Stock, and R. Cooper. 1998. Metabolism and digestibility of corn bran and corn steep liquor/distillers solubles. Nebraska Beef Rep. MP 69-A: 69-71.

Stock, R. A., J. M. Lewis, T. J. Klopfenstein, and C. T. Milton. 2000. Review of new information on the use of wet and dry milling feed by-products in feedlot diets. J. Anim. Sci. 77:1-12.

Van Soest, P. J. 1994. Nitrogen metabolism In: Nutritional ecology of the ruminant. 2nd ed. Cornell Univ. Press, Ithaca, NY. p. 290-311.
Van Soest, P. J., J. B. Robertson, and B. A. Lewis. 1991. Methods for dietary fiber, neutral detergent fiber, and nonstarch polysaccharides in relation to animal nutrition. J. Anim. Sci. 24:834-843.

Williams, C. H., D. J. David, and O. Iismaa. 1962. The determination of chromic oxide in feces samples by atomic absorption spectrophotometry. J. Agric. Sci. 59:381-385. 